\title{
Implementation and application of Dung's model to analyze ductile fracture of metallic material
}

- Hao Nguyen Huu ${ }^{1}$

- Trung N. Nguyen ${ }^{2}$

- Hoa Vu Cong ${ }^{1}$

${ }^{1}$ Ho Chi Minh city University of Technology, VNU-HCM

${ }^{2}$ Purdue University, West Lafayette, IN 47907, USA

(Manuscript Received on August 01 ${ }^{\text {st }}$ 2015, Manuscript Revised August 27 ${ }^{\text {th }}$, 2015)

\begin{abstract}
:
In this paper, the Dung's microscopic damage model which depicts void growth under plastic deformation is applied to predict ductile fractures in high strength steel API X65. The model is implemented as a vectorized userdefined material subroutine (VUMAT) in the ABAQUS/Explicit commercial finite element code. Notched and smooth round bars under uniaxial tension loading are simulated to show the effect

\section{INTRODUCTION}

Ductile fracture of metallic material is usually due to void nucleation, growth and coalescence. To investigate this process, the series of experiments are needed to conduct. This is necessary, but it is quite expensive and time cost. For these reasons, finite element ductile failure simulations based on the local approach is considered as the most effective method and quite useful.
\end{abstract}

Key words: Ductile fracture, Void growth, Dung's model, Micro-crack mechanism

Fracture mechanic based on mechanism of void nucleation, growth and coalescences connect between micro structure variables and macro crack behavior of metallic materials. The plastic failure process due to void nucleation, growth and of equivalent plastic strain versus the void volume fraction growth of the material at and after crack initiation. Predictions of the ductile behavior from void nucleation to final failure stage are compared with the built-in Gurson Tvergaard - Needleman (GTN) model in ABAQUS. Also, comparison with experimental results from the literature is discussed. coalescences includes two phases: homogeneous deformation including void nucleation and growth, local deformation for void nucleation [1]. It is usually use a yield function of porous plastic metallic material model for plastic fracture process analyses. The original yield function is proposed by Gurson [2] based on spherical void growth in 2D space. The Gurson model includes a damage parameter of void volume fraction ( $f$ ). Tvergaard [3, 4] modified the Gurson model by add two adjusted parameters to consider interaction of the voids and hardening by deformation. Needleman and Tvergaard [5] extended Gurson model to simulate rapid loss of 
loading carrying capacity in the void materials. Therefore, Gurson model is also known as GTN (Gurson - Tvergaard - Needleman) model. Base on McClintock [] ] spheroidal void growth model in 3D space, Dung NL [7] investigated the cylindrical and elipsoidal void growth and then proposed a yield function similar to the yield function in GTN model but it includes a hardening exponent (n). Recently, R. Schiffmann et al [] used the Dung's void growth model to predict failure development at ductile fracture of steel, it exhibited good agreement with experiment results. To determine void volume fraction growth during matrix material under deformation, Chu and Needleman [9] supplied the criterions for void nucleation into Gurson model. For the first research about void coalescence criterion: the void coalescences take place only when void volume fraction (f) reaches a critical value (fc). In the later studies found that, fc strongly depend on initial void volume fraction (f0), the size of voids, the space of voids in matrix material, stress triaxiality, strain hardening of material [10, 11]. Thomason [12, 13] proposed a critical loading model that describing of the void coalescence. In this model, at start of void coalescence is controlled by mechanism of plastic localization in the spaces of voids. At these positions, the void coalescence can be explained by material and stress states dependences. Bao [14] conducted the series of experiments and finite element analyses in aluminum alloy 2024T351 and proposed a criterion of void coalescence that based on two parameters of critical equivalent plastic strain $\left({ }^{\varepsilon_{f}}\right)$ and ratio of stress triaxiality $(\mathrm{T})$. When reaches a critical value then void coalescence occurs, mean microcrack will form in matrix material.

In this paper, Dung's model is implemented by a VUMAT subroutine in the finite element software (ABAQUS) to consider process of ductile fracture in high strength steel API X65.
The notch round bars and smooth round bar is simulated to show the effect of equivalent plastic strain on the void volume fraction growth of the materials. The predictions of ductile behavior in the samples from void nucleation to final failure in material are compared with GTN model and experiment results of Oh et el $[15,16]$.

\section{MODELING POROUS PLASTIC METALLIC MATERIAL}

The yield function of Dung's model [7]

$\Phi=\left(\frac{\sigma_{e}}{\sigma_{f}}\right)^{2}+2 f q_{1} \cosh \left[-\sqrt{3}(1-n) \frac{\sigma_{m}}{\sigma_{f}}\right]-1-\left(q_{2} f\right)^{2}=0$

Where, the parameters $q_{1}, q_{2}$ are proposed by Tvergaard [5], $\mathrm{n}$ is hardening exponent of matrix material, hydrostatic stress $\sigma_{m}=-\frac{1}{3} \sigma_{i j} \delta_{i j}$ , $\delta_{i j}$ is Kronecker delta, equivalent stress von Mises $\sigma_{e}=\sqrt{\frac{3}{2} \sigma_{i j}^{\prime}: \sigma_{i j}^{\prime}}, \quad \sigma_{i j}^{\prime}$ is deviatoric stress tensor, $\sigma_{i j}^{\prime}=\sigma_{i j}-\frac{1}{3} \sigma_{i j} \delta_{i j}, \sigma_{i j}$ is stress tensor, $\sigma_{f}$ is the yield stress of matrix material, $\sigma_{f}=\sigma_{f}\left(\bar{\varepsilon}_{e}^{p}\right)$.

The equivalent plastic strain rate of matrix material $\dot{\bar{\varepsilon}}_{e}^{p}$ is dominated by equivalent plastic work:

$(1-f) \sigma_{f} \dot{\bar{\varepsilon}}_{e}^{p}=\sigma_{i j}: \dot{\varepsilon}_{i j}^{p}$

Where, $\bar{\varepsilon}_{e}^{p}$ is equivalent plastic strain of matrix material, $\dot{\varepsilon}_{i j}^{p}$ is plastic strain rate tensor.

The void volume fraction growth is computed as follow:

$$
\dot{f}=\dot{f}_{g}+\dot{f}_{n}
$$

Here, the void volume fraction growth of the presence voids in matrix material:

$$
\dot{f}_{g}=(1-f) \dot{\varepsilon}_{i j}^{p} \delta_{i j}
$$

The nucleated volume void fraction growth during matrix material under deformation:

$$
\dot{f}_{n}=A \dot{\bar{\varepsilon}}_{e}^{p}
$$

The number of nucleated voids $A$ is a function of equivalent plastic strain of matrix material $\bar{\varepsilon}_{e}^{p}$ : 


$$
A=\frac{f_{N}}{s_{N} \sqrt{2 \pi}} \exp \left[-0.5\left(\frac{\bar{\varepsilon}_{e}^{p}-\varepsilon_{N}}{s_{N}}\right)^{2}\right]
$$

Where, $f_{n}, s_{N}, \varepsilon_{N}$ are the parameters relative to the void nucleation during matrix material under deformation.

\section{NUMERICAL IMPLEMENTATION}

This section describes the implementation of the constitutive equations via a VUMAT subroutine in ABAQUS/Explicit software. Aravas [17] proposed a numerical algorithm, based on the Euler backward method, for pressure-dependent plasticity models. First, a trial state of stress is obtained,

$$
\sigma_{i j}^{e}=\left.\sigma_{i j}\right|^{t}+D \cdot \Delta \varepsilon_{i j}
$$

The fourth order tensor $D$ is the elastic stiffness matrix. Isotropic elasticity is assumed so that

$$
D_{i j k l}=\left(K-\frac{2}{3} G\right)\left(\delta_{i j} \delta_{k l}\right)+G\left(\delta_{i k} \delta_{j l}+\delta_{i l} \delta_{j k}\right)
$$

Where, $K$ is the elastic bulk modulus, $G$ is the shear modulus and $\delta_{i j}$ is the Kronecker delta.

For metallic materials the yield surface $\Phi$ is assumed to be identical to the plastic flow potential. The associated flow rule of plasticity is defined as:

$$
\dot{\varepsilon}_{i j}^{p}=\dot{\lambda} \frac{\partial \Phi}{\partial \sigma_{i j}}
$$

with the standard Kuhn-Tucker conditions:

$$
\dot{\lambda} \geq 0, \Phi \leq 0, \dot{\lambda} \cdot \Phi=0
$$

The non-negative scalar $\lambda$ represents the plastic multiplier.

Integration of equation (9) yields:

$$
\begin{aligned}
\Delta \varepsilon_{i j}^{p} & =\Delta \lambda\left(\frac{\partial \Phi}{\partial \sigma_{i j}}\right) \\
& =\Delta \lambda\left[\left(-\frac{1}{3} \frac{\partial \Phi}{\partial \sigma_{m}}\right) \delta_{i j}+\left(\frac{\partial \Phi}{\partial \sigma_{e}}\right) n_{i j}\right]
\end{aligned}
$$

Where, $n_{i j}$ is the unit vector in deviatoric stress space normal to the yield face

$$
n_{i j}=\frac{3}{2 \sigma_{e}} \sigma_{i j}^{\prime}
$$

The increment of plastic strain $\Delta \varepsilon_{i j}^{p}$ can be expressed in terms of volumetric and deviatoric components as:

$$
\Delta \varepsilon_{i j}^{p}=\frac{1}{3} \Delta \varepsilon_{p} I+\Delta \varepsilon_{q} n_{i j}
$$

Where,

$$
\begin{array}{r}
\Delta \varepsilon_{p}=-\Delta \lambda\left(\frac{\partial \Phi}{\partial \sigma_{m}}\right) \\
\text { and } \Delta \varepsilon_{q}=\Delta \lambda\left(\frac{\partial \Phi}{\partial \sigma_{e}}\right)
\end{array}
$$

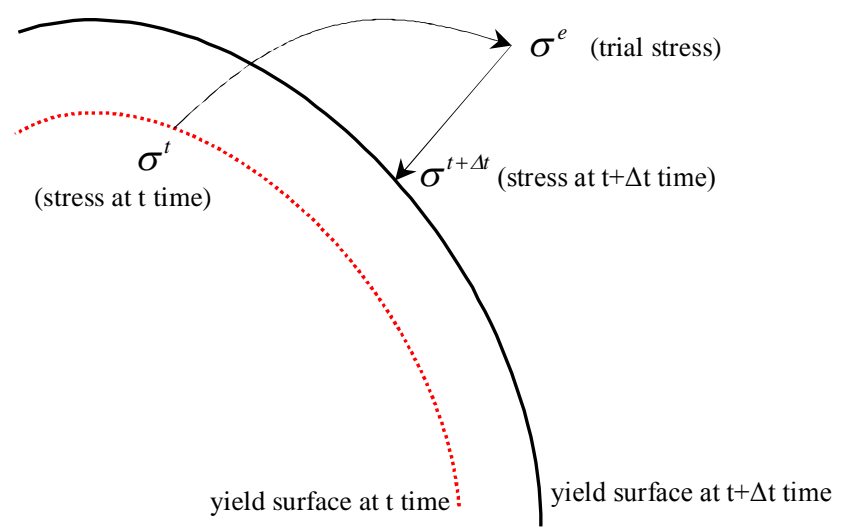

Figure 1. Schematic presentation of the backward Euler algorithm in stress space 
Elimination of $\Delta \lambda$ gives:

$$
\Delta \varepsilon_{q}\left(\frac{\partial \Phi}{\partial \sigma_{m}}\right)+\Delta \varepsilon_{p}\left(\frac{\partial \Phi}{\partial \sigma_{e}}\right)=0
$$

If the yield criterion is violated, the final stress at $t+\Delta t$ is computed through a plastic stress correction, as shown in Figure 1.

$$
\sigma_{i j}^{t+\Delta t}=\sigma_{i j}^{e}-D \Delta \varepsilon_{i j}^{p}
$$

Using equation (13), the term $D \Delta \varepsilon_{i j}^{p}$ can be expressed in terms of the hydrostatic and deviatoric plastic strain components and the elastic bulk $K$ and shear $G$ moduli.

The updated stress state can be written as:

$$
\sigma_{i j}^{t+\Delta t}=\sigma_{i j}^{e}-K \Delta \varepsilon_{p} \delta_{i j}-2 G \Delta \varepsilon_{q} n_{i j}
$$

The stress tensor can be written as:

$$
\sigma_{i j}^{t+\Delta t}=-\sigma_{m}^{t+\Delta t} \delta_{i j}+\frac{2}{3} \sigma_{e}^{t+\Delta t} n_{i j}
$$

from which the stress correction along the hydrostatic and the deviatoric axes becomes apparent:

$$
\begin{aligned}
& \sigma_{m}^{t+\Delta t}=\sigma_{m}^{e}+K \cdot \Delta \varepsilon_{p} \\
& \sigma_{e}^{t+\Delta t}=\sigma_{e}^{e}-3 G \cdot \Delta \varepsilon_{q}
\end{aligned}
$$

Equations (1) and (15), constitute a nonlinear algebraic system of $\Delta \varepsilon_{p}$ and $\Delta \varepsilon_{q}$, which are chosen as the primary unknowns. Using $\partial \Delta \varepsilon_{p}$ and $\partial \Delta \varepsilon_{q}$ as the corrections, the Newton-Raphson equations are

$$
\left[\begin{array}{ll}
\frac{\partial E_{1}}{\partial \Delta \varepsilon_{p}} & \frac{\partial E_{1}}{\partial \Delta \varepsilon_{q}} \\
\frac{\partial E_{2}}{\partial \Delta \varepsilon_{p}} & \frac{\partial E_{2}}{\partial \Delta \varepsilon_{q}}
\end{array}\right]\left\{\begin{array}{l}
\partial \Delta \varepsilon_{p} \\
\partial \Delta \varepsilon_{q}
\end{array}\right\}=\left\{\begin{array}{l}
-E_{1} \\
-E_{2}
\end{array}\right\}
$$

where $E_{1}$ and $E_{2}$ are

$$
\left\{\begin{array}{l}
E_{1}=\frac{\partial \Phi}{\partial \sigma_{e}} \Delta \varepsilon_{p}+\frac{\partial \Phi}{\partial \sigma_{m}} \Delta \varepsilon_{q} \\
E_{2}=\Phi
\end{array}\right.
$$

The equations are solved for $\partial \Delta \varepsilon_{p}$ and $\partial \Delta \varepsilon_{q}$ by means of the Newton-Raphson iterative procedure set up at local material level. The values of $\Delta \varepsilon_{p}$ and $\Delta \varepsilon_{q}$ are then updated:

$$
\left\{\begin{array}{l}
\Delta \varepsilon_{p} \rightarrow \Delta \varepsilon_{p}+\partial \Delta \varepsilon_{p} \\
\Delta \varepsilon_{q} \rightarrow \Delta \varepsilon_{q}+\partial \Delta \varepsilon_{q}
\end{array}\right.
$$

During the iterative procedure, the stress is corrected along the hydrostatic and deviatoric axes $\sigma_{m}$ and $\sigma_{e}$ using equation (19). The void volume fraction $f$ and the equivalent plastic strain $\bar{\varepsilon}_{e}^{p}$ are considered as two scalar internal variables and updated as follows:

$$
\left\{\begin{array}{c}
\Delta f=(1-f) \Delta \varepsilon_{p}+A \Delta \bar{\varepsilon}_{e}^{p} \\
\Delta \bar{\varepsilon}_{e}^{p}=\frac{-\sigma_{m} \Delta \varepsilon_{p}+\sigma_{e} \Delta \varepsilon_{q}}{(1-f) \sigma_{f}}
\end{array}\right.
$$

The algorithm stops iterations when the values of $\left|E_{1}\right|$ and $\left|E_{2}\right|$ are less than a specified tolerance $\delta=1 \mathrm{E}-08$

\section{APPLICATION TO TENSILE TESTING SIMULATIONS}

\subsection{Identifying the parameters for Dung's} model

The properties of material of API X65 steel: Young's modulus $E=210.7 \mathrm{GPa}$, hardening exponent is chosen $n=0 ; 0.134 ; 0.2$, Poission ratio $v=0.3$, initial yield stress $\sigma_{0}=464.5 \mathrm{MPa}$. The experiment data of yield stress and plastic strain curve is refer to Oh [15].

In order to simulate failure process of metallic materials base on void growth and coalescence model, eight parameters have to indentify: two adjustment factors $\left(q_{1}, q_{2}\right)$, six parameters relative to void growth and coalescence $\left(f_{0}, f_{\mathcal{C}}, f_{F}, \varepsilon_{N}, s_{N}, f_{N}\right)$.

The values $q_{1}=1.5 ; q_{2}=1$ are suggested by Tvergaard [4], these values are considered as classical values of GTN model. Koplik and Needleman [18] investigated the void growth and coalescence and found that $q_{1}=1.25$ and $q_{2}=1$ are also good agreement between GTN model and finite element analysis of voided unit cell element. Faleskog et al [19] show that $q_{i}(i=1,2,3)$ there are not dependence on strain hardening exponent (n) and ratio of initial yield stress and elastic modulus $\left(\sigma_{0} / E\right)$. Kim et al [20] found that, for the given material, the parameters $q_{i}$ should be 
changed with ratio of stress triaxiality. For the Dung's model, Dung [7] proposed $\mathrm{q}_{1}=\mathrm{q}_{2}=1.5$.

The void nucleation parameters $\varepsilon_{N}=0.3 ; s_{N}=$ $0.1 ; f_{N}=0.04$ are proposed by Chu and Needleman [9] and widely used by many researchers. For the high strength API X65 steel is the pure steel, during plastic strain process, void nucleation by inclusions and second phase particles is not significant and slow. Therefore, the value $f_{N}$ is chosen 0.0008 .

The initial void volume fraction is calculated based on equation of Franklin [21] as follow:

$$
f_{0}=0.054\left(S \%-\frac{0.001}{M n \%}\right)
$$

Where, $S \%$ and $M n \%$ are weight (\%) of $S$ and $M n$ respectively. The content of these chemical elements is referred to $\mathrm{Oh}$ [15].

The void volume fraction at fracture $f_{F}$ is determined from $f_{0}$ and based on empirical equation of Zhang [1]:

$$
f_{F}=0.15+2 f_{0}
$$

The critical void volume fraction $f_{\mathrm{c}}$ is usually determined by the void coalescence criterions and experiments. In this work, for the API X65 steel, $f_{\mathrm{c}}$ is referred to Oh et al [16].

Summary, the parameters is chosen and calculated as table 1:

Table 1. The parameters for Dung's model

\begin{tabular}{|c|c|c|c|l|c|c|c|}
\hline$\varepsilon_{N}$ & $s_{N}$ & $f_{N}$ & $f_{0}$ & $f_{c}$ & $f_{F}$ & $q_{1}$ & $q_{2}$ \\
\hline 0.3 & 0.1 & $8.0 \mathrm{E}-4$ & $1.25 \mathrm{E}-4$ & 0.015 & 0.15025 & 1.5 & 1.5 \\
\hline
\end{tabular}

\subsection{Testing on single element}

The subroutine is verified using a single 8node brick element (C3D8R) to simulate uniaxial tension. The boundary conditions and loading as shown in figure 2. The initial size of each element edge is $1 \mathrm{~mm}$. The loading velocity $\mathrm{v}_{2}$ for tension is set to $15 \mathrm{~mm} / \mathrm{s}$.

The Figure 3 shows void volume fraction versus equivalent plastic strain for the uniaxial tensile test to single element. For hardening exponent $n=0.134$, the Dung's model coincides with the classical model GTN. Therefore, $n=$ 0.134 is chosen to simulate the notched and round bars in section 4.3.

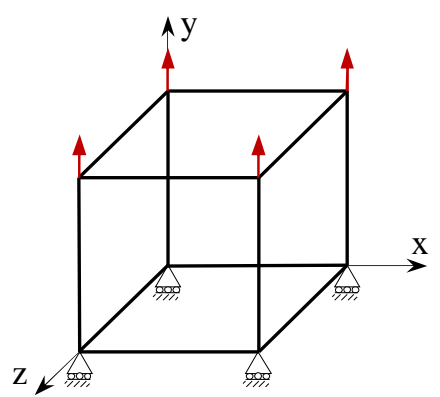

Figure 2. The single element used to verify subroutine

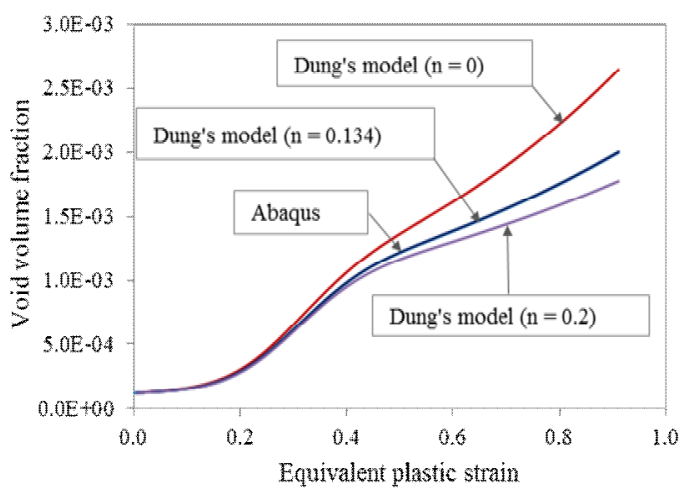

Figure 3. The void volume fraction versus equivalent plastic strain with hardening exponents in yield function of Dung's model

\subsection{Application to the simulation of the notched bar and round bars}

The geometries of tensile specimens as figure 4. Using biaxial symmetry four-node element type with reduce integration (CAX4R). The size of the elements at minimum section are $0.15 \times 0.15 \mathrm{~mm}$, the size of the other elements are $0.15 \times 0.5 \mathrm{~mm}$. Only $1 / 4$ of bar is used to simulate tensile test. The finite element meshes are presented as figure 5.

The velocity loading is applied on top boundary. For each specimen, magnitude of load is chosen and controlled via the critical void volume fraction $\left(f_{c}\right)$ or void volume fraction at fracture $\left(f_{F}\right)$, mean the void volume fraction 
reaches these values, in the matrix material appear initial crack or damage, respectively.
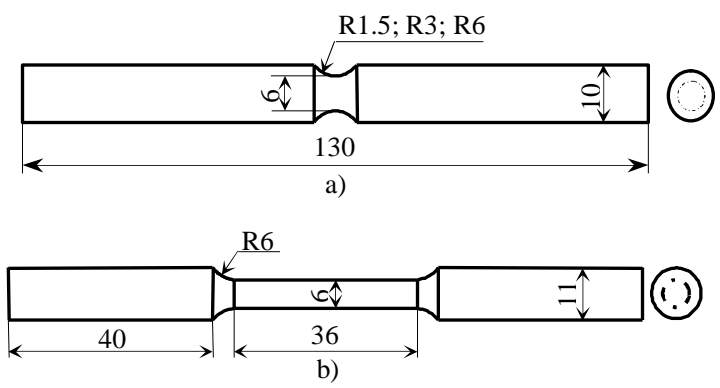

Figure 4. Geometries of tensile specimens; a) notched bars; b) smooth bar

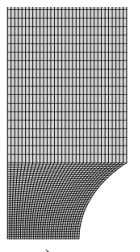

a)

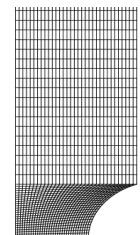

b)

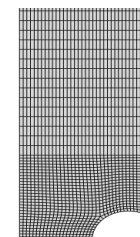

c)

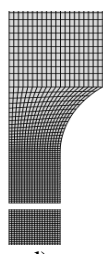

d)
Figure 5. The finite element meshes; a) smooth bar, b) R6 bar; c) R3 bar; d) R1.5 bar

For all the specimens, void volume fraction reachs critical value $\left(f_{c}\right)$ at center of bar earlier than other positions, mean crack initiation occur at these positions before.

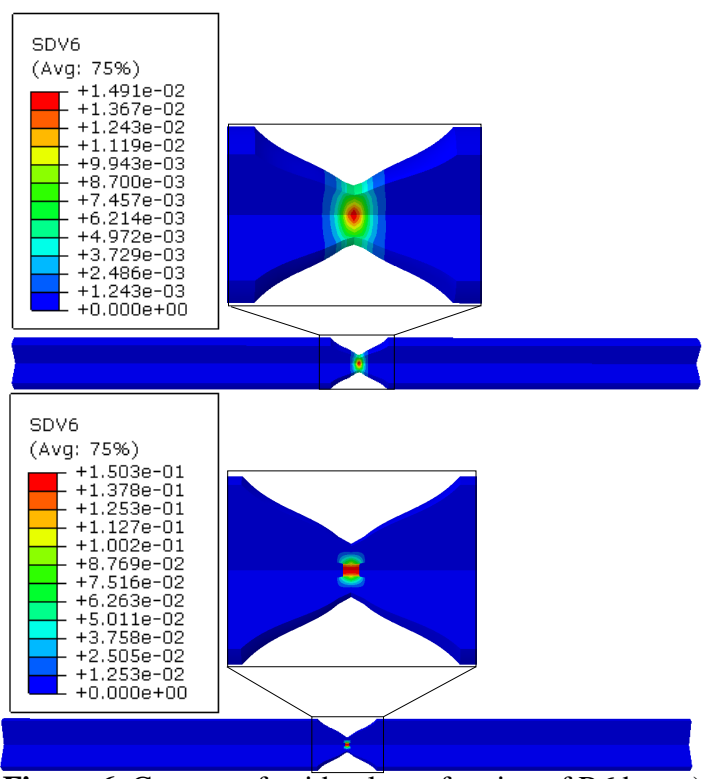

Figure 6. Contour of void volume fraction of R6 bar: a) crack initiation; b) failed elements
The figure 6 shows contour of void volume fraction at and after crack initiation of R6 bar. Figure 7 presents void volume fraction growth (from $f_{0}$ to $f_{c}$ ) versus equivalent plastic strain of element at center of bars for the Dung's model. For the smooth bar, void volume fraction growth reachs critical void volume fraction $\left(f_{c}\right)$ slower the notched bars. Material failes earlier the R1.5 bar than R3 and R6 bar.

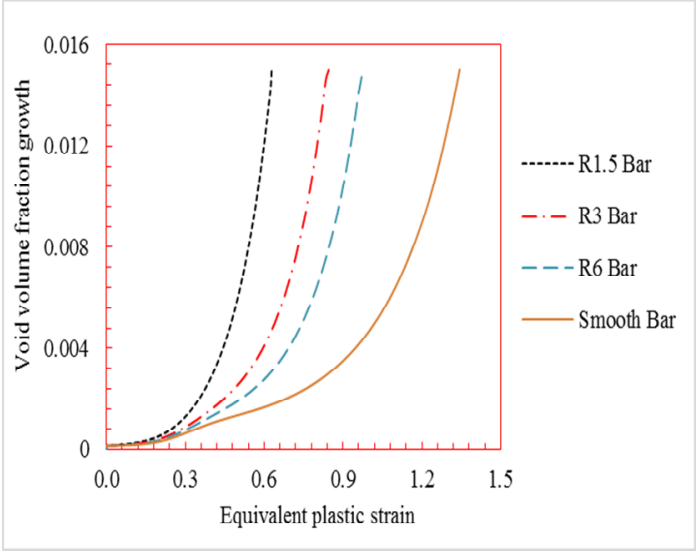

Figure7. Void volume fraction growth versus equivalent plastic strain

Figure 8 shows stress triaxiality versus equivalent plastic strain of center element of bars, the end point of average lines is compared with fracture criterion of Oh [15]

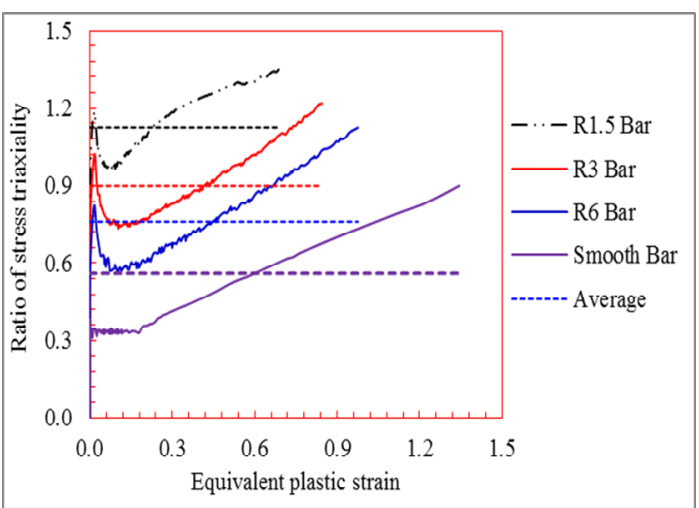

Figure 8. Ratio of stress triaxiality $(-\sigma \mathrm{m} / \sigma \mathrm{e})$ versus equivalent plastic strain

Figure 9 shows comparison between present results and criterion of crack initiation. The fracture strain depend on the stress triaxiality in 
exponential function [22]. For API-X65 steel, Oh et al [15] proposed a critical location criterion that equivalent plastic strain as a function stress triaxiality:

$$
\varepsilon_{f}=3.29 \exp \left(-1.54 \frac{\sigma_{m}}{\sigma_{e}}\right)+0.1
$$

The analysis results of four bars by Dung's model is able to predict the fracture initiation with an acceptable accuracy.

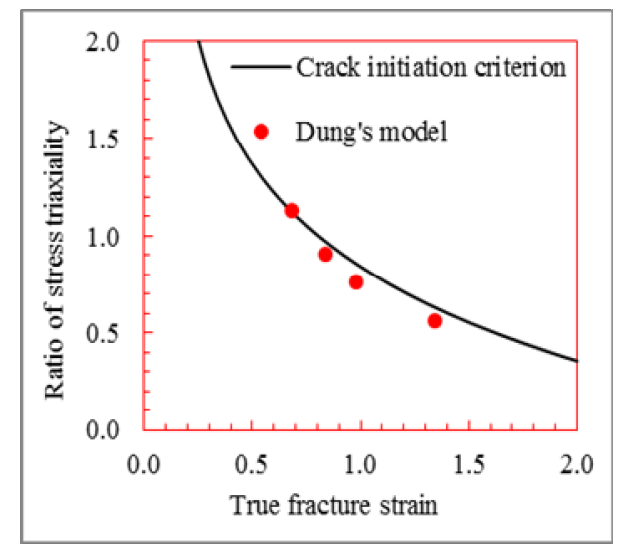

Figure 9. Comparison crack initiation, true fracture strain as a function of stress triaxiality, between Dung's model and fracture criterion of Oh et al [15]

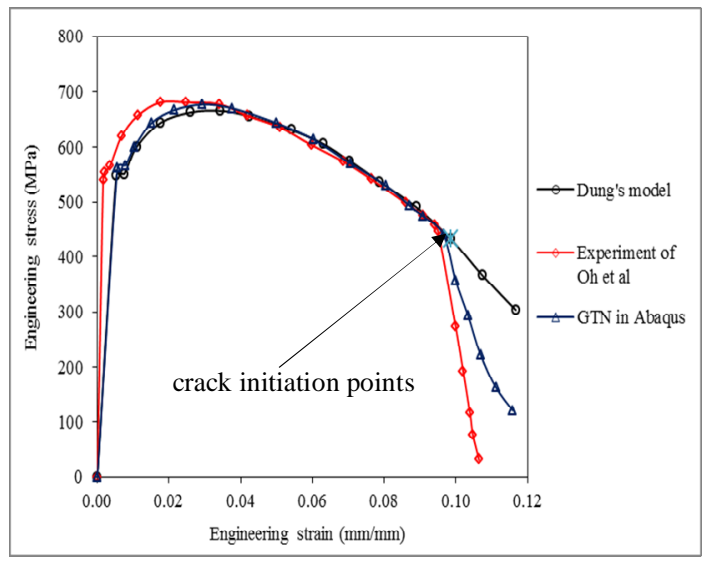

a)

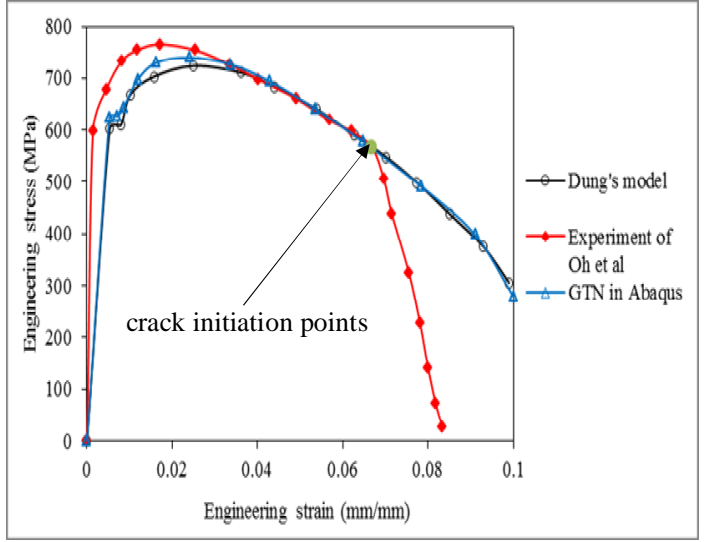

b)

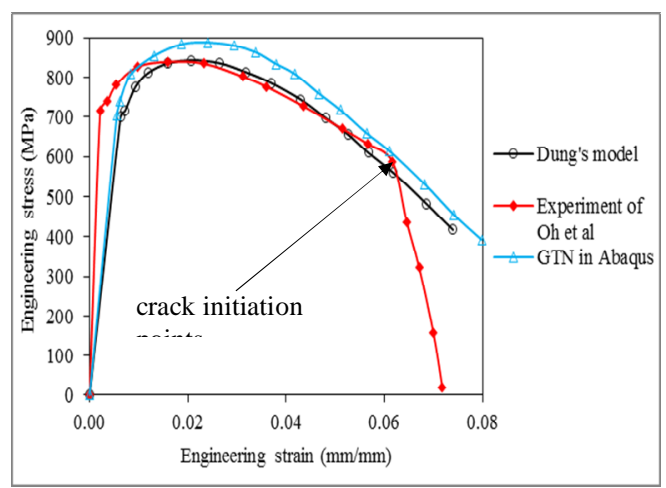

c)

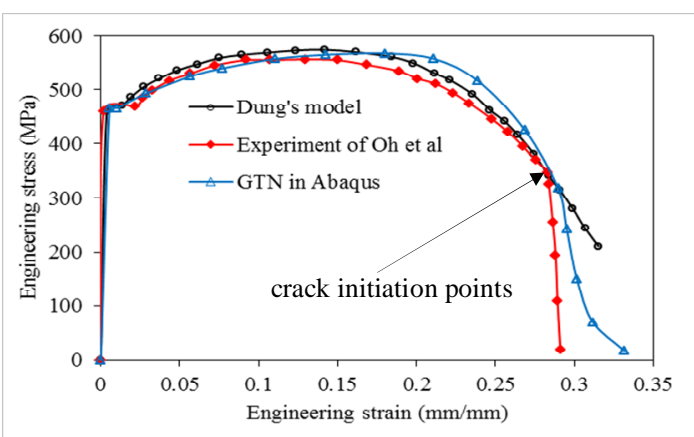

d)

Figure 10. Comparison between simulated results and experiments of Oh et al [15]: a) R6 bar; b) R3 bar; c)

R1.5 bar; d) smooth bar 
In the figure 10 shows engineering stress versus engineering strain of bars. For all the specimens, the results of Dung's model are good agreement with GTN model in Abaqus and experiment results of Oh et al [15].

\section{CONCLUSIONS}

By implemented approach that based on backward Euler method of stress integration for Dung's model succeed in simulating fractured prediction of the notched and round bars. The results provided the predictions of Dung's model are very close to experiment results of $\mathrm{Oh}$ et al $[15,16]$ and GTN model in Abaqus. This work is also show the fractured predictions as follow: for all the specimens, the crack initializes at center and propagates along minimum section of bars; the different geometries crack initializes at different moment. 


\section{Lâp trình và ứng dụng mô hình của Dũng để phân tích nứt dẻo vật liệu kim loại}

- Nguyễn Hữu Hào ${ }^{1}$

- Trung N. Nguyen ${ }^{2}$

- Vũ Công Hòa ${ }^{1}$

1 Trường Đại học Bách Khoa, ĐHQG-HCM

${ }^{2}$ Trường Cơ khí, Đại học Purdue, West Lafayette, IN 47.907, USA

\section{TÓM TÁT:}

Bài báo sử dụng mô hình tăng trưởng lỗ hổng vi mô của Nguyễn Lương Dũng để dự đoán nút dẻo trong thép độ bền cao API X65. Mô hình của Nguyễn Lương Dũng sẽ được lập trình thông qua một chương trình vật liệu do người dùng tự định nghĩa tích hợp trong gói phần mềm phần tử hữu hạn ABAQUS/Explicit. Cụ thể, các thanh tròn có khuyết và thanh tròn trơn sẽ được mô phỏng trong trường hợp chịu kéo đơn trục. Thời điểm hình thành nứt vi mô và thời điểm phá hủy sẽ được dự đoán thông qua các giá trị biến dạng dẻo tương đương tương ứng với sự tăng trưởng tỷ lệ thể tích lỗ hổng vi mô của vật liệu. Kết quả của bài báo cũng sẽ được so sánh với mô hình Gurson - Tvergaard - Needleman (GTN) trong phần mềm thương mại $A B A Q U S$ và các kết quả thực nghiệm tham khảo tùr các công bố quốc tế của các tác giả khác.

Từ khóa: Nứt dẻo, Tăng trưởng lỗ hổng, Mô hình của Dũng, Cơ chế nứt vi mô.

\section{REFERENCES}

[1]. Zhang, Z., Thaulow, C. and Ødegård, J. A Fract, 18, 4 (1982/04/01 1982), 237-252. complete Gurson model approach for ductile fracture. Engineering Fracture Mechanics, 67, 2 2000), 155-168.

[2]. Gurson, A. L. Continuum Theory of Ductile Rupture by Void Nucleation and Growth: Part I-Yield Criteria and Flow Rules for Porous Ductile Media. Journal of Engineering Materials and Technology, 99, 1 1977), 2-15.

[3]. Tvergaard, V. Influence of voids on shear band instabilities under plane strain conditions. Int J Fract, 17, 4 (1981/08/01 1981), 389-407.

[4]. Tvergaard, V. On localization in ductile materials containing spherical voids. Int $J$

[5]. Tvergaard, V. and Needleman, A. Analysis of the cup-cone fracture in a round tensile bar. Acta Metallurgica, 32, 1 (1// 1984), 157-169.

[6]. McClintock, F. A. A Criterion for Ductile Fracture by the Growth of Holes. Journal of Applied Mechanics, 35, 2 1968), 363-371.

[7]. Dung, N. L. Three Dimensional Void Growth in Plastic Materials. Mechanics Research Comunications, 19, 3 1992), 227.

[8]. Schiffmann, R., Dahl, W. and Bleck, W. Different CDM-models and their ability to describe the damage development at ductile fracture of steel. City, 2013.

[9]. Chu, C. C. and Needleman, A. Void 
Nucleation Effects in Biaxially Stretched Sheets. Journal of Engineering Materials and Technology, 102, 3 1980), 249-256.

[10].Pardoen, T. and Hutchinson, J. W. An extended model for void growth and coalescence. Journal of the Mechanics and Physics of Solids, 48, 12 (12// 2000), 24672512.

[11].Zhang, Z. L., Thaulow, C. and Odegard, J. A complete Gurson model approach for ductile fracture. Engineering Fracture Mechanics, 67, 2 (9/1/ 2000), 155-168.

[12].Thomason, P. F. A three-dimensional model for ductile fracture by the growth and coalescence of microvoids. Acta Metallurgica, 33, 6 (6// 1985), 1087-1095.

[13]. Thomason, P. F. A View on Ductile Fracture Modelling. Fatigue \& Fracture of Engineering Materials \& Structures, 21, 9 1998), 1105-1122.

[14].[14] Bao, Y. Dependence of ductile crack formation in tensile tests on stress triaxiality, stress and strain ratios. Engineering Fracture Mechanics, 72, 4 (3// 2005), 505522.

[15].Oh, C.-K., Kim, Y.-J., Baek, J.-H. and Kim, W.-s. Development of stress-modified fracture strain for ductile failure of API X65 steel. Int J Fract, 143, 2 (2007/01/01 2007), 119-133.

[16].Oh, C.-S., Kim, N.-H., Kim, Y.-J., Baek, J.-
H., Kim, Y.-P. and Kim, W.-S. A finite element ductile failure simulation method using stress-modified fracture strain model. Engineering Fracture Mechanics, 78, 1 (1// 2011), 124-137.

[17].Aravas, N. On the numerical integration of a class of pressure-dependent plasticity models. International Journal for Numerical Methods in Engineering, 24, 7 1987), 13951416.

[18].Koplik, J. and Needleman, A. Void growth and coalescence in porous plastic solids. International Journal of Solids and Structures, 24, 8 (// 1988), 835-853.

[19].Faleskog, J. and Shih, C. F. Micromechanics of coalescence-I. Synergistic effects of elasticity, plastic yielding and multi-sizescale voids. Journal of the Mechanics and Physics of Solids, 45, 1 (1// 1997), 21-50.

[20].Kim, J., Gao, X. and Srivatsan, T. S. Modeling of void growth in ductile solids: effects of stress triaxiality and initial porosity. Engineering Fracture Mechanics, 71, 3 (2// 2004), 379-400.

[21].Benedetti, M. and Fontanari, V. The transferability of micro-mechanical damage parameters in modern line pipe steel. City, 2013.

[22].Rice, J. R. and Tracey, D. M. On the ductile enlargement of voids in triaxial stress fields*. Journal of the Mechanics and Physics of Solids, 17, 3 1969), 201-217. 